KAMIL LIPIŃSKI

Galeria Sztuki Współczesnej Garbary 48

\title{
OBRAZ DZIEDZICTWA TONY'EGO GARNIERA W MIEJSKICH MURALACH
}

Rozpocznijmy od spostrzeżenia, że zmienność współczesnych przeobrażeń turystyki pozwala nam twierdzić coraz częściej, iż ich kierunek zmierza w stronę „inscenizowania” autentyczności wyobrażonych miejsc i przykuwania uwagi do dziedzictwa estetycznego. Obrazem takich punktów otwierających przestrzeń dla nowoczesnej turystyki są mozaikowe, fantazyjne fasady przynależne do obszaru praktyki turystycznej, kształtujące tym samym swoistą enklawę. Interesować mnie będzie perspektywa „turystycznej adaptacji dziedzictwa kulturowego", uchodząca za przedmiot doświadczenia zbiorowego, w którym „historyczność” i „autentyczność” stanowi symptom „fascynacji obiektami historycznymi i śladami”, zwłaszcza zaś nostalgii ${ }^{1}$. Przyjęta optyka, opisująca hiperrzeczywistą formę modernizacji, obiera sobie za cel przywrócenie zapomnianych sfer planowania przestrzeni. Dzisiejszy turysta ma do wyboru „szereg gier i scenariuszy” pozwalających na to, aby potencjalne obiekty turystyczne wniosły jakąś różnicę. Były niecodzienne w sytuacji, kiedy „gra on z wieloma tekstami kultury, a nie z jakimś konkretnym”2.

Przedmiotem naszej uwagi jest próba uchwycenia, jak zabawa, różnorodność wyraża estetykę ,złożonych struktur miejsc pamięci” pojmowanych za Paulem Ricoeurem w kategoriach tego, co „materialne, symboliczne i funkcjonalne”’. Jedną z ważniejszych cech takiego kreatywnego osadzenia dziedzictwa historycznego jest ustalenie, jak: „pierwsze zakotwicza miejsca pamięci $\mathrm{w}$ realiach, o których można powiedzieć, że są całkowicie dane i poręczne; drugie jest dziełem wyobraźni i to zapewnia krystalizowanie się wspomnień i ich przekazywanie; trzecie prowadzi z powrotem do rytuału, który wszakże historia chce usunąć, co obserwujemy w przypadku wydarzeń czy widowisk założycielskich, miejsc schronienia $i$ innych sanktuariów"4. Jednocześnie zarysowana strategia upiększania miejsc odzwierciedla nam w mozaikowy sposób obraz tego, co historycznie zapomniane ${ }^{5}$.

\footnotetext{
1 J. Urry, Spojrzenie turysty, przeł. A. Szulżycka, Warszawa 2007, s. 155.

${ }^{2}$ Ibidem, s. 150.

${ }^{3}$ P. Ricoeur, Pamięć, historia, zapomnienie, przeł. J. Margański, Kraków 2006, s. 538.

${ }^{4}$ Ibidem.

5 J. Urry, op. cit., s. 24.
} 
W poniższej analizie skupmy się na badaniu tego, co Ricoeur nazywa „śladem dokumentalnym”. Według Ricoeura „dokument to nie tylko niemowa, ale i sierota; świadectwa, jakie zawiera, oderwały się od autorów, którzy powołali je do życia"’ . Celem niniejszego szkicu jest zatem nakreślenie specyfiki jednego z najważniejszych niezrealizowanych planów miejskich Une Cité Industrielle Tony'ego Garniera naszkicowanych u progu XX wieku jako „miejsc pamięci” oraz próba udowodnienia, w jaki sposób „turyzm z kolei wzbogaca semiotykę, będąc dowodem na to, że szczególne cechy społecznego i naturalnego świata są artykułowane poprzez, jak nazwał je Percy, «symboliczne kompleksy» i ujawniając, że nowoczesna pogoń za doświadczeniem jest pogonią za doświadczeniem znaków"8.

Zarysowana optyka kreśli wizję planów architektonicznych widzianych w dialektycznej perspektywie, rozwartej między „tu i teraz”, aby uchwycić pamięciową specyfikę miejsca. Jedną z najważniejszych cech miejsc pamięci (lieux de mémoire), jak pisał Pierre Nora, jest tendencja do podkreślania, iż są one „otwarte na dialektykę pamiętania i zapominania, nieświadome swej sukcesywnej deformacji, podatne na manipulację i zawłaszczenie, mogą trwać w uśpieniu i co jakiś czas się budzić" . Ożywioną i ambiwalentną specyfikę przekształceń pamięci możemy oglądać w formie przedstawień historycznych odzwierciedlających dialektykę przeszłości i teraźniejszości „Historia jest zawsze problematyczną i niepełną rekonstrukcją tego, czego już nie ma (...) gdyby historia nie zawłaszczała pamięci, deformując ją i przekształcając, przenikając i paraliżując, nie istniałoby lieux de mémoire" ${ }^{10}$. Powrót do tego, co utracone, bądź zapomniane, określa dynamikę późnego kapitalizmu odnajdywaną w obrazach przestrzennych. Z tego punktu widzenia futurystyczny projekt Garniera wpisany w nowe ramy można postrzegać jako przykład kształtowania „postindustrialnego asamblażu”11.

Rozważmy wspomnianą problematykę, nawiązując do debaty poświęconej demokratyzacji kultury i dziedzictwa regionu, rozpatrując ją przez pryzmat zaangażowania w turystykę i oscylację między przeszłością i nowoczesnością. Przedmiotem naszej analizy jest kompleks murali wykonany przez francuską grupę artystyczną Cité de la Creation, w lyońskiej Dzielnicy Stanów Zjednoczonych utworzonej na przedmieściach miasta obok niedawno zrealizowanych Mur des Canuts, Fresque des Lyonnais, Bibliothéque de la Cité, Goethe Theatre des Charpennes etc. W gronie trzystu pięćdziesięciu prac wykonanych przez tę grupę w kilku miastach we Francji oraz w Barcelonie, Meksyku, Lipsku, Lizbonie, Wiedniu, Jerozolimie, Quebecu, na szczególną uwagę zasługuje dwadzieścia pięć murali stworzonych na przedmieściach Lyonu. W tej zaś grupie chciejmy zatrzymać się przy projekcie rewitalizacyjnym obejmującym dziesięć obiektów renowacji dziedzictwa kulturowego Tony'ego Garniera.

Przedsięwzięcie rozpoczęto w 1985 roku od budynku Wielkiego Biura Publicznego Rozwoju i Konstrukcji OPAC. Punktem wyjścia dla tej realizacji jest utworzenie i wyko-

${ }^{6}$ P. Ricoeur, op. cit., s. 221.

${ }^{7}$ Ibidem, s. 224.

8 J. Culler, Semiotyka turyzmu, przeł. H. Baczewska, „Panoptikum” nr 9/2009, s. 20.

9 P. Nora, Między pamięciq a historia, przeł. P. Mościcki, „Archiwum” nr 1/2009, s. 7.

${ }^{10}$ Ibidem.

${ }^{11}$ S. Lash, Refleksyjność i jej sobowtóry: struktura, estetyka, wspólnota, przeł. J. Konieczny, w: Modernizacja refleksyjna, Warszawa 2009, s. 178. 
nanie estetycznej kompozycji fasad, zlecone malarzom z Cité de la Création w 1988 roku. Dziesięcioletnie wówczas przedsiębiorstwo podjęło się przyobleczenia w nowe barwy miejskiej przestrzeni na przedmieściach Lyonu. Estetyzacja objęła miejskie obiekty w publicznej i prywatnej przestrzeni przez odsłonięcie, zaznaczenie i ornamentowanie środowiska. Poszczególne murale umieszczono na fasadach budynków w obrębie osiedli mieszkaniowych w Loyer Moderne (HLM). Lyońskie osiedle w Dzielnicy Stanów Zjednoczonych otwiera się zatem „na wizyty turystyczne ze względu na obecność dwudziestu pięciu murali na powierzchni większej niż 55000 metrów kwadratowych ulokowanych w sąsiedztwie klasy pracującej"12. Dziesięć z tych malowideł poświęcono planom modernistycznym Tony’ego Garniera, sześć kolejnych międzynarodowych prezentacji dopełnia publiczny projekt mieszkaniowy obejmujący szkice „Idealnych miast świata”. Nakreślone przeobrażenia znajdują swoją artykulację w kontekstach historycznych na fasadach osiedla mieszkaniowego widzianego z perspektywy geografii relacyjnej celem wydobycia specyfiki różnic estetycznych zarysowanej w badaniach geografii artystycznej (Kunstgegraphie) ${ }^{13}$. Podstawową cechą geografii relacyjnej jest analiza miejsc w kategoriach różnic estetycznych. Mozaikowe plany rozbudowy osiedli podmiejskich wykraczają poza esencjalizm kulturowy po to, aby skierować się, jak wiele dzieł z zakresu mapowania obrazów, w stronę uprzestrzennienia. Zarysowany punkt widzenia określa ,potrzebę wielosubiektywności”, jaka cechuje „krytyczny proces geograficznej specjalizacji” i jednocześnie przy tym charakteryzuje ,wielozamieszkiwanie” przestrzeni przez ciała, relacje społeczne ${ }^{14}$. Owa optyka charakteryzująca rozrysowanie mapy pozwala na artykulację rozwiązań i redefinicję dotychczasowych narracji pod kątem kartograficznych badań ujmowanych w kategoriach „praktyki znaczącej lokacji i tożsamości, sposobu pisania, przez który możemy odkryć zestaw praw generalnych"15. Stanowiąc jedno z ważniejszych świadectw futurologii historycznej zarysowane plany przestrzenne przyczyniły się do budowy grands ensembles w Lyonie. Kompleksowa organizacja osiedla pozwoliła zarazem na rozwój, organizację działań kulturalnych, dyseminację nowych wyobrażeń pośród mieszkańców, a także ich implementację, zarządzanie i opłacanie robotników. Projekt Muzeum Miejskiego Tony’ego Garniera powstał w efekcie powiązania historii w Dzielnicy Stanów Zjednoczonych przeznaczonej dla klasy pracującej i skromnych rodzin. Projekt modernizacyjny planów miejskich utworzony na przełomie XIX i XX wieku można przyrównać do efektu powstającgo poprzez wyeksponowanie ,widoków panoramicznych"16 kinematografu Braci Lümiere. Projekt Une Cité Industrielle Tony Garniera nakreślony na fasadach budynków postrzegamy jako miejsca pamięci budujące panoramiczną scenerię uwikłaną w kontekst doświadczenia przechodniów. W tej perspektywie wyłania się zeń to, co ,jednocześnie proste i dwuznaczne, naturalne i sztuczne, bezpośrednio dostępne w konkretnym zmysłowym doświadczeniu i podatne na najbardziej abstrakcyjne przekształcenia" ${ }^{17}$. Ostatecznie rekonstruk-

12 A. Chavez, From Tony Garnier to the Urban Museum: the birth of a cultural housing project, "Museum International" no. 223 (vol. 56, no. 3/2004), s. 77.

13 P. Piotrowski, On Spatial Arts or Horizontal Art History, „Umeni” no. 5/ 2008, s. 380.

${ }^{14}$ I. Rogoff, Terra Infima. Geography's Visual Culture, New York 2000, s. 23.

15 Ibidem.

16 J. Aumont, L'oeil interminable, Paris 1995, s. 31.

17 Ibidem. 
cje planów Tony’ego Garniera rozrysowane w kilkudziesięciostopniowym odchyleniu perspektywicznym wywołują wrażenie cyfrowej animacji i wydobywają dwoisty charakter tych miejsc. Obrazy te są rekonstrukcją pejzaży widzianych w różnych konfiguracjach po to, aby udowodnić, iż „miasto-panorama jest «teoretycznym» (to znaczy, wzrokowym) (...) obrazem, którego warunkiem zaistnienia jest zapomnienie lub nieznajomość praktyk"18.

Chciejmy tym miejscu wyróżnić dwa aspekty geografii artystycznej, z których pierwszy z nich wskazuje na ich kompleksowy charakter, drugi z punktu widzenia precyzyjnej syntezy pozwala na uchwycenie przestrzennych relacji w kulturze celem pojednania aspektu geograficznego i artystycznego. Modernistyczna wizja przestrzeni klasy robotniczej wykracza poza kanon ówczesnych realizacji. Mieszkańcom oferowano bardzo dobre warunki mieszkaniowe. Postępowa treść społeczna sygnalizowana w projekcie Une Cité Industrielle zyskała miano ,pierwszego manifestu nowoczesnej urbanistyki w równym stopniu we Francji, co w skali międzynarodowej ${ }^{19}$ ". Projekt ten wykonany w latach 1899-1917 zawdzięczał swoją nazwę poparciu Garniera dla przystąpienia wojsk Stanów Zjednoczonych do I wojny światowej i żywionej przez niego nadziei na pozytywne zakończenie konfliktu. Jednocześnie można go określić próbą wprowadzenia postępowych i utopijnych rozwiązań konstrukcyjnych niemożliwych jeszcze wtedy do realizacji. Powrót do dzieł Tony Garniera nastąpił podczas pierwszej retrospektywy w paryskim Musée d'Art Décoratif w 1925 roku. Stanowi on punkt wyjścia dla rozwoju nowoczesnej architektury francuskiej ${ }^{20}$. Wyrazem stopniowej rehabilitacji tych projektów była organizacja wystawy poświęconej architektowi lyońskiemu w Mediolanie i w Paryżu w latach 60. XX wieku mających na celu uwypuklenie wartości awangardowych i społecznych zarysowanego planu.

Plany przestrzenne nakreślone na lyońskich muralach odzwierciedlają przeobrażenia przełomu wieków, powiązane z wdrażaniem nowatorskich projektów zainicjowanych Wystawami Światowymi w Paryżu w latach 1855, 1867, 1878, 1889, 1900. Warto podkreślić, że istotną rolę na Wystawie Światowej w 1889 roku odegrały Wieża Eiffla i Galerie des Machines Ferdinanda Duterta i Victora Contamina zapoczątkowująca korelację formy i funkcji. Pierwsze wzmianki o swoim projekcie Garnier sformułował dziesięć lat później, w trakcie pobytu na stypendium w Académie de Français w Rzymie w latach 1899-1904, a efekty przedstawił na 164 planach na Wystawie Światowej w 1904 roku ${ }^{21}$. Ważną inspiracją dla planów Garniera była powieść Le Travail (1901) Émila Zoli poświęcona perypetiom młodego przemysłowca w mieście, u podstaw którego legły socjalistyczne przesłanki Charlesa Fouriera. Projekt ten, pomimo zamiaru wprowadzenia innowacyjnych koncepcji, spotkał się z niepochlebną oceną architektonicznych autorytetów z Institute de France skutkującą zaniechaniem jego realizacji. Za jedną z przyczyn odrzucenia projektu należy uznać jego rozpiętość, podobnie jak w przypadku budowy stolicy Brazylii wynikającą z wprowadzenia rozwiązań dopiero testowanych w mikroskali. Le Corbusier zarzucał Garnierowi zwłaszcza to, iż konstrukcja Cité nie wyróżniała się wystarczającą gęstością. Paradoksalnie, ,ambiwalencja” charakteryzująca ten projekt, świadczy z perspektywy czasu o jego

\footnotetext{
18 M. de Certeau, Wynaleźć codzienność. Sztuki działania, przeł. K. Thiel-Janczuk, Kraków 2008, s. 94.

19 K.K. Pawłowicz, Tony Garnier. Pionier urbanistyki nowoczesnej, Warszawa 1972, s. 7.

20 Ibidem.

21 P. Rabinow, French Modern. Norms and Forms of Social Environment, Chicago 1995, s. 217.
} 
„reprezentacyjnej i normatywnej sile”22. Korzystając z ówczesnych innowacji, Garnier sięgnął po największe osiągnięcie lat 90. XIX wieku - elektryczność umożliwiającą poszerzenie pola w architekturze i planowaniu, co stanowiło podstawowy element „EXPO 1900”. Garnier przedstawił problematykę generowania siły elektrycznej i wprowadził w swoim planie hydroelektryczne rozwiązania ${ }^{23}$. Do zalet regulacji utopijnej cité (w sensie polis) zaliczmy zwłaszcza: „transformację historyczno-naturalnego milieu w produktywne i spokojne środowisko" ${ }^{24}$. Rozwiązania arkadowe pochodzące z rezydencji Villa Medici Garnier zaaranżował w swym projekcie podczas wizyty w Rzymie. W trakcie tego pobytu zapożyczył też poszczególne formy architektoniczne z amfiteatru Villa Borghese imitujące atmosferę Morza Śródziemnego ${ }^{25}$. Wprowadzone przez niego rozwiązania formalne miały posłużyć do aranżacji krajobrazu i konstruowania ustawień architektonicznych, pejzażowych w formie ,arkad"26.

Projekt Garniera zakładał zagwarantowanie przestrzeni dla postępowego nurtu ruchów robotniczych w środowisku lyońskim, będąc jednym z planów budowy mieszkań robotni$\operatorname{czych}^{27}$. Tamtejsza sekcja Towarzystwa Tanich Mieszkań funkcjonowała równolegle z centralą paryską, a w 1892 roku mogła pochwalić się osiedlem złożonym z sześćdziesięciu domów robotniczych $\mathrm{w}$ Oullins pod Lyonem ${ }^{28}$. Pierwsze projekty przestrzenne Garnier naszkicował na planach Lyonu w 1895 roku po to, aby zagospodarować tereny usytuowane na brzegu Saony w pobliżu „,nadbrzeża przemysłowego" ${ }^{29}$. Odpowiadał on tym samym na zapotrzebowanie nowego przemysłu motywowane politycznymi przemianami gospodarowania przestrzennego wprowadzonymi przez mera miasta Edouarda Hérriota - protoplastę procesu modernizacji i odrodzenia narodowego oraz postępowej myśli łączącej poszczególne grupy społeczne. Wychowany w dzielnicy robotniczej Croix Rousse Tony'ego Garniera nie zrywał kontaktu z problemami tej klasy. W szczególności zaś ten Architecte-en -chef de la ville de Lyon dawał szansę wprowadzenia proponowanych zmian ${ }^{30}$. Jego projekt nowoczesnego społeczeństwa wiązał się z realizacją idei dobra wspólnego zarysowanego

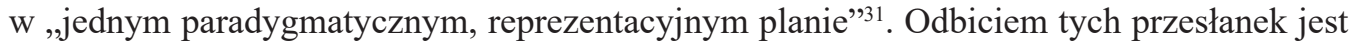
mural obrazujący spojrzenie na współczesne mieszczańskie życie na poszczególnych piętrach. O sukcesie planów Garniera ,po czasie” zadecydował fakt, że socjalistyczni reformatorzy i oświeceni koloniści, do których należy zaliczyć Huberta Lyauteya z Maroko, dostrzegali w nim prekursora późnego modernizmu, a w jego projekcie wszechstronne aspekty nowoczesnego planowania społeczeństwa ${ }^{32}$. Wzrastające znaczenie Lyonu w regio-

\section{Ibidem.}

${ }^{23}$ D. Wieberson, Utopian aspects of Tony Garnier's Cité Industrielle, „The Journal of the Society of Architectural Historians" vol. 19, no. 1 (Mar., 1960), s. 21.

\footnotetext{
24 P. Rabinow, op.cit., s. 54.

25 Ibidem, s. 20.

${ }^{26}$ D. Wieberson, op. cit., s. 23.

27 K.K. Pawłowicz, op.cit., s. 4.

28 Ibidem.

29 Ibidem.

${ }^{30}$ D. Wieberson, op. cit., s. 16.

31 P. Rabinow, op. cit., s. 217.

32 Ibidem.
} 
nie i w kraju stało się przyczynkiem rozwoju innych ośrodków i rozbudowy systemu linii kolejowych. Sam zaś projekt Cité Industrielle zakładał wskrzeszenie jedności pracowniczej. Szczególną uwagę zwróćmy na plan starego miasta umiejscowiony nad rzeką, który stanowił ,jeden z elementów historycznego milieu"33 mając na celu ufundowanie porządku obiektów w nowym mieście. Nieopodal w dzielnicy przemysłowej wyposażonej w „metalurgiczne fabryki i futurystyczne wzornictwo cementowe" 34 przewidziano wzniesienie dzielnicy mieszkalnej wyposażonej w strefy pieszych, licea i technikum, miejsca opieki nad dzieckiem. Z kolei budowę szpitali projektowano w „wybranym miejscu przylegającym do wzgórz, dokąd dochodziło najwięcej światła słonecznego" "35. Do najważniejszych elementów tego projektu należy zaliczyć obiekty rekreacyjne, zwłaszcza zaś sportowe oraz teatr i park, jakie powstały w efekcie usytuowania administracji w centrum miasta. Cechuje ten projekt nadto nieobecność sądów i komisariatów policji oraz obiektów administracyjnych i masowych zgromadzeń publicznych. W zamian zaś przewidział on budowę budynku przeznaczonego do kultywowania pamięci historycznej „w centralnym kompleksie administracyjnym”, ,w pustym budynku uchodzącym za miejsce archiwizacji”36.

Do podstawowych elementów przestrzennej organizacji miasta należy regionalizm mający na celu „łączenie tego, co stare z tym, co nowe"37. Równie ważnym aspektem regionalnego rozwoju miasta jest konceptualizacja przestrzeni zapożyczona od Viollet-le-Duca na określenie konieczności uchwycenia więzów łączących naturę fizyczną wraz z historią i jej mieszkańcami, z rozwojem przemysłowym i handlowym. Jednocześnie przy tym uniwersalistyczną myśl przestrzenną wywodził Garnier od Vidala de la Blanche’a, zdaniem którego nauki społeczne powinny zrobić miejsce dla ekologii określanej mianem „najbardziej geograficzn[ej] z humanistyki" ${ }^{38}$. Tym, co wyróżnia ten projekt jest jednoczesny związek z ogólnie akceptowaną zasadą konieczności polegającą na współdziałaniu w tych badaniach różnych dyscyplin ${ }^{39}$. Zwróćmy jednocześnie uwagę na dwa czynniki opisujące „pragnienie idealnej kondycji ignorującej wiele problemów istniejącego społeczeństwa” w niezrealizowanym projekcie Garniera. Można w nim wyróżnić obrazy przesycone „realizmem zmierzającym do zakładanej kondycji aktualności i myśli w większym szczególe"40. Projekt modernizacji Dzielnicy Stanów Zjednoczonych zarysowany na tych planach przez Tony’ego Garniera stanowi punkt wyjścia dla formowania i zawiązywania relacji z ruchem francuskiego regionalizmu. Przyczynił się ten ruch ukształtowany w latach 80 . i 90. XIX wieku do „rozwoju prowincjonalnych obszarów Francji, regionalnych uniwersytetów, lokalnych muzeów historycznych, miejsc kierujących rdzenną sztukę i rzemiosło w obszar lokalnego przemysłu"41. W wyniku podziału historycznego milieu na starą i nowoczesną część miasta nad rzeką z jednej strony, budynki zwracały się w kierunku głów-

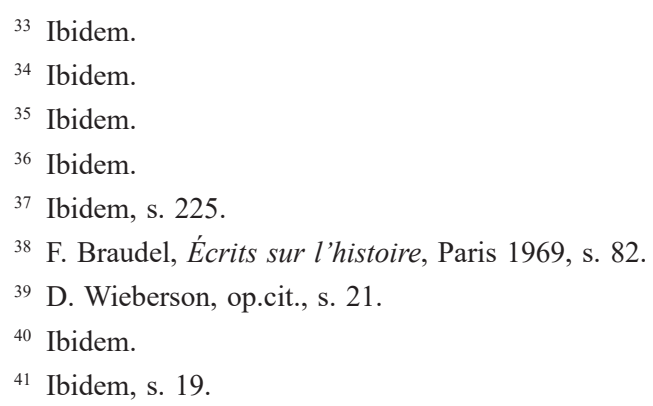


nego dworca kolejowego, z drugiej zaś, ku górom. Bierze się stąd horyzontalne usytuowanie budynków, w kontekście geograficznym wpisujące się w dziedzictwo narodowe regionu w zabudowie mieszkalnej.

Projekt Cité Industrielle opracowany przez Garniera w willi Medyceuszy dotyczył także związku organizacyjnego czterech głównych sektorów: przemysłowego, mieszkalnego, administracyjnego i przeznaczonego na ośrodki zdrowia ${ }^{42}$. Każda z wymienionych dzielnic i przydzielona jej funkcja wiązała się z niezależnym usytuowaniem jej w przestrzeni. W szczególnej mierze Garnier ,żywo i koherentnie demonstrował podział na strefy będący jednym ze znaków rozpoznawczych nowoczesnego planowania"43. Wyrazistą cechą tych planów utrzymaną w duchu socjalistycznych przesłanek jest jej „forma lokalna, nieoficjalna, kolektywna - ale jednocześnie mocno zindywidualizowana"44. Warto też zauważyć, iż ambiwalentne podejście Garniera polegało na konsekwentnej eliminacji baraków armii, więzienia, komisariatów policji, sądów, co było odbiciem wizji bezpieczeństwa i pokoju, rezygnował nadto z obiektów własności prywatnej, nie przewidział też rozwoju kompleksu obejmującego miejsca zgromadzeń publicznych i wielkich hal widowiskowych. Organizacja miasta opierała się na funkcjonalnym rozmieszczeniu akcentów, a każdą dzielnicę postrzegano jako miniaturę miasta samego w sobie. Dzięki temu Paul Rabonow pisał, iż „społeczna samoregulacja mogłaby być osiągnięta przestrzennie" 45 . Należy w tym miejscu wskazać na połączenie w utopijnej topografii Lyonu Garniera „przestrzeni rolniczej, przemysłowej, miejskiej, nakładającej się na i wchłaniającej jedna drugą" "46. Planowane usytuowanie poszczególnych obiektów uchodziło za istotne narzędzie mające posłużyć pewnym interesom wiedzy, dzięki swym względnym projekcjom przestrzennym i każdorazowemu wyznaczeniu określonej perspektywy. Do mankamentów tego projektu należy natomiast zaliczyć fakt, iż Garnier nie przedstawił żadnych planów sfinansowania go.

Dzisiaj zaś wielokulturowa aranżacja wernakularnych ,miejsc pamięci” w Lyonie będąca projektem modernizacji krystalizuje się jako efekt przestrzennych wyobrażeń przeniesionych z planów miejskich w futurystyczną przestrzeń fasad dostępnych pro publico bono dla lokalnych mieszkańców i turystów. Przywrócenie pamięci planów miejskich można określić mianem lustrzanego odbicia w podmiejskiej części Lyonu lat osiemdziesiątych obejmującego swoim zagospodarowaniem środowisko osiedla mieszkaniowego przez murale „wielkości ponad trzystu metrów kwadratowych”, „wiernie kreujące atmosferę lat trzydziestych, wyposażone w przewodniki audio i rekonstrukcję oryginalnych projektów"47. Za jedną z ważniejszych zalet kompleksu murali należy uznać upamiętnienie kreowane poprzez utworzenie aranżacji i uchwycenie panoramicznych przedstawień historycznych. Jest ono „momentem lieux de mémoire”, kiedy to „znika rozległy i głęboki zasób pamięci, który można ocalić jedynie jako odtworzony obiekt spojrzenia historii krytycznej"48.

\footnotetext{
42 P. Rabinow, s. 222.

43 Ibidem.

44 Ibidem, s. 228-229.

45 Ibidem, s. 232.

46 H. Lefebvre, La révolution urbaine, Paris 1970, s. 168.

47 A. Chavez, op. cit., s. 83.

48 P. Norra, op. cit., s. 6
} 
Unikatowa na skalę europejską wielokulturowa różnorodność zebranych murali sprawiła, iż kompleks budynków w Dzielnicy Stanów Zjednoczonych zdobył nagrodę UNESCO w 1991 roku oraz trofea turystyczne w 2002 roku przyznawane za publiczne zaangażowanie przez francuski rząd, a także nagrodę Twentieth Century w 2003 roku. Konstruktorzy Cité de la Création zwracali uwagę na zewnętrzną estetykę powierzchni budynków dwuspadowych ścian i oryginalny plan Cité Industrielle. Eddie Gilles Di Pierno podczas swojej kadencji podjął się w swojej polityce miejskiej misji zbierania funduszy na renowację sąsiedztwa po to, by umożliwić mieszkańcom odegranie aktywnej roli w programowaniu i implementacji operacji jego ulepszania. Budowa sąsiedztwa zakładała alokowanie publicznych funduszy i atrybucję dodatkowych publicznych zasobów do obszarów poddawanych estetyzacji. W ramach inwestycji sięgającej wysokości dwóch milionów franków w przestrzeń publiczną, milion dwieście tysięcy został przeznaczony na realizację murali. Muzeum Tony'ego Garniera, jako główna instytucja usytuowana w Le quartier des États-Unis, funkcjonuje na podstawie regularnych subwencji oraz z dotacji turystów odwiedzających dzielnicę i wystawy, w przestrzeni których przewija się ich przeszło dwadzieścia tysięcy rocznie. Środowisko Dzielnicy Stanów Zjednoczonych połączone z symbolicznymi wyobrażeniami miast idealnych stanowi jedno $z$ wielu skromnych lub średniej wielkości instytucji miejskich opartych na wsparciu finansowym Państwa. Obrana strategia „upamiętniania” planom przestrzennym przydała charakteru „śladu, mediacji, dystansu”, wyłaniających się w „hiperrzeczywistej formie”. Projekt Cité de la Création odzwierciedla to, jak: ,zgromadzone murale przedstawiają ewolucję artystyczną linearnego malarstwa muralowego i figuratywnego w politycznej (...) formie (zwłaszcza meksykańskiego i, o wiele mniej znanego, malarstwa powstałego w Stanach Zjednoczonych podczas okresu New Deal)"49. Zaprezentowane na muralach przeobrażenia przestrzeni klasy pracującej, jej architektury, inicjatyw i rozwiązań funkcjonalno-społecznych artykułują to, co Ricoeur nazywa „nadwyżką znaczenia” względem autentycznego doświadczenia styku z inną rzeczywistością kulturową. Tym samym stanowią one istotny punkt wyjścia $\mathrm{w}$ debacie na temat kategorii demokratyzacji kultury i dziedzictwa. Można by rzec, iż wraz z wprowadzeniem planów modernizacji miejskiej Garniera w przestrzeń publiczną „stare miejsce obrazów stało się nowym miejscem kultur, w odróżnieniu od technicznego archiwum fotografii, filmów i muzeów, w którym przechowuje się obrazy"50. Zakorzenione w tej mozaikowej poetyce lyońskie murale przeciwstawiają, jak powiada Nora: „naszą historyczną perspektywę panoramicznemu dystansowi, a nasze sztuczne hiperurzeczywistnienie przeszłości ostatecznemu wyobcowaniu, tak też zmienny sposób postrzegania kieruje historyk, prawie wbrew jego woli, ku tradycyjnym obiektom, od których się odwrócił, ku obiegowej wiedzy zawartej w naszej narodowej pamięci”s1.

Jednocześnie otwarta przestrzeń przeznaczona dla uczestników poruszających się w obszarze różnorodnych murali tworzy obraz dobra wspólnego. Wykracza poza granice państw narodowych, celem krystalizacji międzykulturowej mozaiki wpisanej w środowisko murali etnicznych. Rozwiązania urbanistyczne zainicjowane w organizacji regionalnego modelu Dzielnicy Stanów Zjednoczonych pozwoliły na realizację międzykulturowej platformy. Zwłaszcza zaś opiera się ona próbie nakreślenia reprezentacji pamięci ujętej jako obszar

\footnotetext{
49 Ibidem.

${ }^{50}$ H. Belting, Antropologia obrazu. Szkice o nauce o obrazie, przeł. M. Bryl, Kraków 2012, s. 330.

${ }^{51}$ Ibidem.
} 
dialogu europejskiego dziedzictwa z teraźniejszością poprzez mimetyczne przeformułowanie wieloetnicznych projektów i identyfikacji. Omawiane specyficzne ukształtowanie planów miejskich Garniera wykorzystanych w muralach namalowanych na fasadach budynków mieszkalnych można określić jako wyraz „strategicznego uwypuklenia, dobierania próbek i mnożenia przykładów" 52 . Wspomnianym przedstawieniom planów Garniera towarzyszy sześć projektów międzynarodowych. Obejmują one mozaikę symboli społeczno -kulturowych reprezentujących Meksyk, Egipt, Wybrzeże Kości Słoniowej, Rosję i Stany Zjednoczone. Przybierają one postać niezwykle pomysłowej formy osadzonej między duchowością, tożsamością etniczną a emblematami każdej z kultur.

W świetle niniejszych ustaleń upamiętniające kompleksy murali można uznać za jeden z ważniejszych symptomów ,reakcji wspólnotowej przeciwko indywidualizmowi i pozwalają na rozwiązywanie kwestii istotnych społecznie, mniejszości etnicznych przez aktywność, tematykę i wspólną pracę"53. Zarysowana tekstura planów przestrzennych widziana z perspektywy przechodnia odzwierciedla multikulturowe wyobrażenie sześciu projektów „Miast Idealnych” oraz jednocześnie oddaje związki dziedzictwa narodowego z regionem lyońskim. Trafnie ową monumentalność pokazuje słowa Pierre’a Nory, wedle którego; „,budowana jednoznaczność, pilnie strzeżona przez miejskich kronikarzy, materializuje się w postaci pomników, nazw ulic, placów itd., które są najważniejszymi obiektami troski miejskich służb porządkowych"54.

Projekt Dzielnicy Stanów Zjednoczonych można zatem określić jako kolejny etap włączenia peryferii miejskich w itineraria podróży turystycznych. Tym samym buduje on atrakcyjny wizerunek rozplanowania przestrzennego i strategicznej artes memoriae dziedzictwa estetycznego widzianej w powszechnej formie dostępnej każdemu ze zwiedzających. Refleksyjna modernizacja pozostawia ślad przemyśleń o nowoczesności i restrukturyzacji miejskiej widzianej w postaci futurystycznych projektów przełomu XIX i XX w. wpisanych $\mathrm{w}$ życie lokalne mieszkańców z jednej strony, i osadzonych $\mathrm{w}$ nomadycznym przepływie turystów przechadzających się w otwartych przestrzeniach ekspozycyjnych z drugiej. To turystyczne zwiedzanie na wolnym powietrzu w Dzielnicy Stanów Zjednoczonych ,jest nie tylko wyzwoleniem, ale także czerpaniem rozkoszy z urzeczonego patrzenia" ${ }^{5}$. Sygnalizowany pęd ku restauracji tego, co kiedyś pomijane, i jednoczesna legitymizacja pamięci społecznej pozwała na zaznajomienie się z planami myśli futurystycznej umieszczonymi na fasadach osiedla mieszkaniowego w otwartej panoramie będącej obszarem konsumpcji wizualnej. Kompleks Dzielnicy Stanów Zjednoczonych godzien jest szczególnej uwagi jako kolejny etap w rozwoju otwartych przestrzeni, w której to wpisuje widza w grę wizualną ze zmieniającym się otoczeniem i umożliwia komponowanie zeń swojej własnej wędrówki.

52 Ibidem, s. 9.

53 F.P. Popper, Art, anti-art, ville, w: La ville n'est pas un lieu, „Revue Esthétique” nr 3-4/1977, s. 229.

54 N. Leśniewski, Miasto i jego miejsca. Próba ujęcia radykalno-hermeneutycznego, w: Pisanie miasta, czytanie miasta, red. A. Zeidler-Janiszewska, Poznań 1997, s. 52.

55 R. Krauss, Optyczna podświadomość, przeł. M. Bryl, „Artium Questiones” nr. XVI/2005, s. 235. 


\title{
Bibliografia
}

Aumont J., L'oeil interminable, Paris 1995.

Bachman-Medick D., Cultural Turns, Nowe kierunki w historii nauk o kulturze, przeł. K. Krzemieniowa, Warszawa 2012.

Belting H., Antropologia obrazu. Szkice o nauce o obrazie, przeł. M. Bryl, Kraków 2012.

Braudel F., Écrits sur l'histoire, Paris 1969.

Certeau M. de, Wynaleźć codzienność. Sztuki działania, przeł. K. Thiel-Janczuk, Kraków 2008.

Culler J., Semiotyka turyzmu, przeł. H. Baczewska, „Panoptikum” nr 9/2009.

Chavez A, From Tony Garnier to the Urban Museum: the birth of a cultural housing project, "Museum International" no. 223 (vol. 56, no. 3/2004),

Krauss R., Optyczna podświadomość, przeł. M. Bryl, „Artium Questiones” nr XVI/2005.

Lash S., Refleksyjność i jej sobowtóry: struktura, estetyka, wspólnota, przeł. J. Konieczny, w: Modernizacja refleksyjna, Warszawa 2009.

Lefebvre H., La révolution urbaine, Paris 1970.

Leśniewski N., Miasto i jego miejsca. Próba ujęcia radykalno-hermeneutycznego, w: Pisanie miasta, czytanie miasta, red. A. Zeidler-Janiszewska, Poznań 1997.

Nora P., Między pamięcia a historia, przeł. P. Mościcki, „Archiwum” nr 1/2009.

Pawłowicz K.K., Tony Garnier. Pionier urbanistyki nowoczesnej, Warszawa 1972.

Piotrowski P., On Spatial Arts or Horizontal Art History, „Umeni” no. 5/ 2008.

Popper F.P., Art, anti-art, ville, w: La ville n'est pas un lieu, „Revue Esthétique” nr 3-4/1977.

Rabinow P., French Modern. Norms and Forms of Social Environment, Chicago 1995.

Ricoeur P., Pamięć, historia, zapomnienie, przeł. J. Margański, Kraków 2006.

Rogoff I., Terra Infima. Geography's Visual Culture, New York 2000.

Urry J., Spojrzenie turysty, przeł. A. Szulżycka, Warszawa 2007.

Wieberson D., Utopian aspects of Tony Garnier's Cit Industrielle, „The Journal of the Society of Architectural Historians" vol. 19, no. 1 (Mar., 1960).

\section{KAMIL LIPIŃSKI}

\section{The image of Tony Garnier's legacy in urban murals}

\begin{abstract}
Summary
The article addresses artes memoriae perceived as documentary traces of a spatial project which has slipped to oblivion, namely Une Cité Industrielle by Tony Garnier from 1917, redefined by Cité de Création in the context of urban housing. The movement, revolving around modern philosophies of urban planning and launched at the turn of the 19th and 20th centuries assumed elimination of private property, equality of the working class and division into zones. It also restored the concept of the relations between nature, history of the inhabitants, industrial and historical development of Viollet-Le-Duc functionality and locality. A contemporary cluster of murals creates a mosaic of historical memorial spaces and contributes to Lyon's development in a new form.
\end{abstract}

Keywords: staging, murals, memorial spaces, regionalism, historical heritage. 